\title{
ÂLEMIN YARATILMASI PROBLEMİ: İBN TUFEYL-KANT KARŞILAŞTIRMASI
}

\section{Aykut Küçükparmak*}

$\ddot{\mathbf{O z}}$

Âlemin yaratılması meselesi felsefe ve teolojinin en tartışmalı konularından biridir. Bu problem bir taraftan zamanın mahiyetiyle bir taraftan da Tanrı'nın iradesi ve Tanr1zaman ilişkisi gibi bizatihi çözülmesi zor meslelelerle ilgilidir. Problemin bu doğası biri âlemin k1demini biri de âlemin hudûsunu savunan iki temel yaklaşımın ortaya çıkmasına neden olmuştur. Ancak bunlardan birisini tercih etmedeki güçlükler, bu konuda aklın sınırları içinde bilgi sabibi olamayacağımız şeklinde üçüncü bir görüşün ortaya çıkmasına neden olmuştur. Bu görüşün en tipik iki savunucusu İbn Tufeyl ve Kant'tır. Bu konu hakkında iki filozof arasındaki benzerlik, İbn Tufeyl'in Kant'ın öncüsü olduğu iddialarının ortaya atılmasına neden olmuştur. Ancak gerek Kant'ın İbn Tufeyl'den etkilendiğine dâir doğrudan ifadelerin bulunmaması gerekse de yapılan bazı itirazlar bu iddia üzerine bir değerlendirme yapmayı gerekli kılmaktadır. Bu çerçevede ilk olarak Kant'ın İbn Tufeyl'den etkilenmiş olmasının mümkün olup olmadığı üzerine bir değerlendirme yapmak gerekli görünmektedir. İkinci olarak da iki filozofun konuyla ilgili görüşlerinin içerik yönünden karşılaştırılması gerekmektedir. Bu hususların dikkate alınması İbn Tufeyl ve Kant arasındaki etkileşime dâir iddiaları değerlendirmemize imkân veren bir zemin teşkil edecektir.

Anahtar Kelimeler: İbn Tufeyl, Kant, Kıdem, Hudûs, Antinomi

\section{THE PROBLEM OF CREATING THE WORLD: COMPARISON OF IBN TUFAYL-KANT}

\begin{abstract}
The problem of creating the world is one of the most controversial issues in philosophy and theology. This problem related to one hand the nature of time and on the other hand issues that difficult such as, the will of God and the relationship between God-time. This nature of the problem led to the emergence of two basic approaches, one defending the eternality of the world and one defending the creation of the world. However, the difficulties in choosing one of these have led to the emergence of a third opinion, such as at this topic we cannot be get knowledge within the limits of reason. The two most typical advocates of this view are Ibn Tufayl and Kant. The similarity between the two philosophers on this subject led to the assertion that Ibn Tufayl was the pioneer of Kant.
\end{abstract}

Article Types/Makale Türü: Research Article/Araştırma Makalesi

Received/Makale Geliş Tarihi:18/06/2019, Accepted/Kabul Tarihi: 01/09/2019

Doi: 10.26791/sarkiat.579512

* Dr. Öğr. Üyesi, Muş Alparslan Üniversitesi, Fen Edebiyat Fakültesi, Felsefe Bölümü, a.kucukparmak@gmail.com

ORCID ID: https://orcid.org/0000-0002-5565-9377 
However, both the lack of direct statements that Kant was influenced by Ibn Tufayl and some objections made it necessary to make an assessment on this claim. In this framework, it seems necessary to evaluate first, whether it is possible for Kant to be influenced by Ibn Tufayl. Secondly, the views of the two philosophers on the subject should be compared in terms of content. Consideration of these issues will provide a basis for us to evaluate the claims regarding the interaction between Ibn Tufayl and Kant.

Keywords: Ibn Tufayl, Kant, Eternality, Creation, Antinomy

\section{GíRiş}

Bir bütün olarak âlemin yaratılması problemi hem felsefe hem de teolojinin en çok tartışılan ve en çetrefil konularının başında gelir. Uzun bir geçmişe sahip bu problem çerçevesinde genel olarak iki temel yaklaşımın var olduğu söylenebilir. Bunlardan birincisi çoğunlukla İbrahimî dinî geleneğe bağlı teologların savunduğu ve bir bütün olarak kozmik var oluşun yoktan meydana geldiğini ve muayyen bir zamanda başladığını ifade eden yoktan yaratma ya da hûdus görüşüdür. Buna karşılık ikinci görüş ise, çoğunlukla Aristotelesçi geleneğe bağlı filozofların öne sürdüğü ve âlemin zamanda bir başlangıcının var olmadığını dile getiren kıdem görüşüdür. Bununla birlikte bu iki temel yaklaşımın dışında âlemin zamanda bir başlangıcı olduğu veya sonsuz olduğu görüşlerinden birinin aklî gerekçelerle tercih edilemeyeceğini dile getiren üçüncü bir görüşten de söz edilebilir. Bu yaklaşım, esas itibariyle âlemin yaratılması lehinde ve aleyhindeki delillerin eşit güçte olduğunu ve bu nedenle de bunlardan biri lehinde aklın sınırları içerisinde kalarak bir yargıda bulunmanın mümkün olmadığını ifade eder. $\mathrm{Bu}$ görüşü en sistematik olarak dile getiren iki düşünür İbn Tufeyl (d.1105-ö.1185) ve Immanuel Kant (d.1724-ö.1804) olarak ifade edilebilir. Şüphesiz farklı medeniyet havzalarına mensup ve farklı dönemlerde yaşamış bu iki düşünürün âlemin yaratılması ile ilgili görüşlerinin ne ölçüde benzer olduğu ve aralarında bir etkileşimin olup olmadığına dâir bir inceleme oldukça ilgi çekici olacaktır. Bu çerçevede çalışmamızın amacını Kant'ın birinci antinomideki âlemin yaratılmasıyla ilgili görüşleri ile İbn Tufeyl'in görüşleri arasındaki benzerliği incelemek ve Kant'in bu konuda İbn Tufeyl'den etkilenmiş olduğu iddiasını değerlendirmek olarak belirledik.

$\mathrm{Bu}$ bağlamda ilk olarak ifade edilmesi gereken şey, Kant'ın İbn Tufeyl'den etkilendiğine dâir doğrudan herhangi bir beyanının ve açık kanıtın bulunmadığı hususudur. Bu nedenle Kant'in birinci antinomide İbn Tufeyl'in görüşlerinden etkilenip etkilenmediğine dâir bir inceleme öncelikle böyle bir etkileşimin imkanına dâir tarihî arka planın araştırılmasını gerektirir. Açıktır ki yalnızca böyle bir imkânın ortaya konması tek başına Kant'ın İbn Tufeyl'den etkilendiği iddiasını temellendiremez. Buna ilaveten ve daha belirleyici olarak yapılması gereken şey, bu iki düşünürün konu hakkındaki argümanlarının içerik yönünden karşılaştırmaları yapılarak, benzerliğin ne ölçüde olduğunu incelemek olacaktır. Bu doğrultuda ilk olarak Ibn Tufeyl'in Batı felsefesi ve modern dönem filozofları üzerindeki etkisine dair bir değerlendirme oldukça yararlı olacaktır.

\section{Ibn Tufeyl'in Batı Felsefesine Etkisi}

İbn Tufeyl'in tek felsefi eseri olan Hayy Bin Yakzan birçok açıdan özgün olan ve Ortaçağın en etkili eserlerinden biri olarak ifade edilebilir. Bu eserinde İbn Tufeyl, meşrikî felsefenin mahiyetini, tabiat-insan ilişkisi temelinde tüm etkilerden uzak bir 
insanın duyu idrakinden başlayan bir süreçle hakikate nasıl ulaşabileceğini ve hakikate dair ulaştığı bu sonuçlarla vahyî bilginin uygunluğunu göstermek gibi çok önemli felsefi problemleri ele almayı amaçlar. İbn Tufeyl işaret ettiğimiz bu problemleri adada yalnız başına olan bir karakter kurgusu üzerinden ele alır. Şüphesiz ne ele aldığı felsefi problemler ne de eserin kurgusal çerçevesi tamamen yeni değildir, ancak basit bir kurguyu felsefi öneme sahip eşsiz bir romana dönüştürme başarısı ona özgüdür (Sıddıki, 1990: 152). İşte İbn Tufeyl'in bu başarısı ve ele aldı̆̆ 1 felsefi problemlere dair sergilediği özgün yaklaşımlar, Hayy Bin Yakzan eserini, Sarton'un ifadesiyle "Ortaçağların en orijinal eserlerinden biri” haline getirmiştir (1931: 354).

Bu özellikleri vesilesiyle Hayy Bin Yakzan romanı hem İslam felsefesi geleneğinde hem de geç dönem Batı felsefesi üzerinde derin etkiler bırakmıştır. Avrupa'da bu romanın ilk çevirisi Moses of Norbonne tarafından 1349'da İbraniceye yapılmıştır. Daha sonra 15. Yüzyılın ikinci yarısında Rönesans'ın önemli isimlerinden Pico della Mirandola tarafından Latinceye çevrilmiştir. Daha sonra bu çevirileri Oxford'da profesör olan Edward Pococke'nin Arapçadan Latinceye ikinci bir çevirisi (1671) ve Felemenkçe (1672) ve İngilizce (1674) gibi diğer Avrupa dillerine çevirileri izlemiştir (Attar, 2007: 16). $\mathrm{Bu}$ olgu tek başına Hayy Bin Yakzan'ın modern Batı düşünürleri tarafından erişilebilir olduğunu ve yaygın bir şekilde dolaşımda olduğunu gösterir niteliktedir.

Bu çerçevede birçok kimse Hayy Bin Yakzan'ın modern dönemin önemli filozoflarının temel görüşleri üzerinde derin etkileri olduğunu öne sürmektedir. Örneğin Hawi Hayy Bin Yakzan üzerine yaptığı incelemenin sonucunda, onun tabiatı deneyim ve gözleme dayalı anlama yaklaşımının, Bacon'un modern bilim anlayışının öncüsü olarak görülebileceğini öne sürer. Buna ilaveten Locke'un epistemolojik tespitlerinin ve Spinoza'nın evrensel töz fikrinin arkasında yatan harekete geçirici etkinin Hayy Bin Yakzan'daki yaklaşımlarda bulunabileceğini belirtir (1974: 255-256). Benzer şekilde Voltaire, Descartes, Rousseau ve Kant gibi düşünürlerin de farklı konularda İbn Tufeyl' in Hayy Bin Yakzan kitabından etkilendiği (Al-Rodhan, 2012: 17) literatürde dile getirilen örneklerden bazıları olarak ifade edilebilir.

Şüphesiz İbn Tufeyl'in Batı filozofları üzerindeki etkilerinin boyutu ve detayları konumuzun sınırlarını oldukça aşan bir meseledir. Bizim bu çerçevede asıl dikkat çekmek istediğimiz husus, bu etkileşime dair bazı cüzi örneklere temas ederek, bu bağlamda karşılaşılan bazı temel problemlere işaret etmektir. Bu bize Kant'ın birinci antinomide Tufeyl'den etkilendiğine dair iddiaları ele almaya izin veren bir zemin sağlayacaktır.

$\mathrm{Bu}$ çerçevede en ilginç örneklerden biri, Gul Russel'ın Locke'un İbn Tufeyl'den etkilenmiş olma ihtimali üzerine yaptığı çarpıcı değerlendirmede bulunabilir. $\mathrm{Bu}$ incelemede Russel, birkaç açıdan İbn Tufeyl'in Locke'un epistemoloji alanındaki görüşleri üzerinde derin etkileri olduğunu göstermeye çalışır. Bu doğrultuda ilk olarak Hayy Bin Yakzan'da deneyimden başlayarak bilgiyi inşa etme yaklaşımı ile Locke'un emprist epistemolojisinin temel dayanakları arasındaki içerik benzerliği ve Locke'un bu konuları ele almasının Hayy Bin Yakzan'ın çevrilmesinden hemen sonrasına tekabül etmesi olgularını ele alır. Russel bu hususu şu şekilde ifade eder:

Burada doğrudan sorulması gereken soru bu benzersiz romanın ortaya çıkması ve [İnsan Anlı̆̆ Üzerine Bir] Deneme'nin birinci versiyonundaki Locke'un taslağının tamamen rastlantı olup olmadığı ya da aralarında bir bağlantının olup olmadığıdır. Böyle bir soru ortaya atmanın sebebi Oxford'da Philosophus autodidactus [Kendi başına öğrenen filozof]'un yayınlanmasının Locke'un 
entelektüel kariyerinde bir dönüm noktasına rast gelmesidir. Uzmanlar, Locke'un yazılarında zihnin doğası ve onun doğuştan idealar olmaksızın deneyimden meydana geldiği meseleleri üzerine ilk kez 1671'de odaklandığı konusunda büyük ölçüde hemfikirdir. Bu emprik yaklaşım Locke'un bilgi teorisinin özünü oluşturur... Bu dönemden önce Locke'un ilgisi sosyal, politik ve pratik konular üzerineydi ve Deneme'sindeki epistemolojik türden meseleler üzerine özel bir ilgisi yoktu (Russel, 1994: 224).

$\mathrm{Bu}$ değerlendirme çerçevesinde Hayy Bin Yakzan'ın içeriği dikkate alındığında, onun toplumdan ayrı ve hiçbir öğretmeni bulunmayan yalnız bir kimsenin duyumla başlayıp akletmeyle ilerleyen bir süreçte doğa, ahlak ve Tanrı hakkında nasıl bilgi sahibi olabileceği gibi meseleleri, açıktır ki Locke'un Deneme'deki temel tezleriyle doğrudan bir örtüşme içerisindedir denilebilir. Dahası Locke'un Deneme'nin ilk kitabında doğuştan fikirler olmadığını göstermek için kullandığ1 'hiç öğrenim görmemiş çocuk' ya da 'ormanların vahşi bir sakini' gibi semboller ve adadaki bir çocuğun doğuştan bir Tanrı fikrine sahip olamayacağı, bu fikre ancak şeylerin oluşumunu ve sebeplerini incelemek için kendi aklını kullanarak ulaşabileceği gibi yaklaşımları (Zaken, 2017: 214), Hayy Bin Yakzan'ın içeriğiyle doğrudan bir benzerliği açıkça göstermektedir. Yukarıda da işaret ettiğimiz üzere, bu içeriksel benzerliğe ilaveten Locke'un zihnin doğası ve onun deneysel kökenlerine dair meselelere ancak Philosophus autodidactus'un çevirisinden sonra yönelmesi olgusunu da dikkate alındığımızda, bu durumun Locke'un İbn Tufeyl'den haberdar olduğunu ve ondan etkilendiğini göstereceği sonucunu çıkarmak oldukça makul görünmektedir.

Öte yandan Russel, Locke'un Hayy Bin Yakzan'dan haberdar olduğunu göstermek için yalnızca içeriksel benzerliği ele almaz. Buna ilaveten Locke'un Philosophus autodidactus'un çevirmeni baba oğul Pococke ile yakın ilişkisini ve bu kitaptan haberdar olan arkadaş çevresini de ayrıntılı bir şekilde inceleyerek (Russel, 1994: 234246), bu durumu Locke'un Hayy Bin Yakzan'dan haberdar olduğunu gösteren bir olgu olarak değerlendirir. $\mathrm{Bu}$ ilişki ağını ortaya koyduktan sonra Locke'un bu kitaptan haberdar olduğu konusunda makul hiçbir şüphe olmadığı yargısında bulunur:

Bu koşullar, Locke'un Philosophus autodidactus'la ilgili ayrıntılı bilgi sahibi olması hususunun makul bir şüpheden uzak olduğunu kanıtlar. O, yalnızca onu kitaptan habersiz tutmak isteyen ya da ondan çalışmayı gizleyen büyük bir komplonun kurbanıysa bu kitaptan haberdar olmayabilirdi (Russel, 1994: 252).

İbn Tufeyl'in modern dönem Batı fillozofları üzerindeki etkisi bağlamında diğer çarpıcı bir örnek Spinoza'dır. Daha önce İbn Tufeyl'den etkilenen filozoflar arasında ondan söz etmiştik. Ancak Spinoza'yla ilgili dikkate değer olan husus, onun belirli konularda Tufeyl'den etkilenmiş olmasından çok Hayy Bin Yakzan'1 Hollandacaya ilk kez çeviren kişi olduğuna dair iddiayla ilgilidir. Bu çerçevedeki tartışmalar Hayy Bin Yakzan'ın Hollandacaya ilk çevirisinde çevirmenin adının açıkça bulunmamasından kaynaklanır. Ancak bu doğrultuda yapılan çalışmalardaki bulgular çevirmenin Spinoza olduğunu gösterecek niteliktedir.

Bayraktar "Hayy Bin Yakzan'ın Çevirmeni Olarak Spinoza” isimli makalesinde bu bulgulara işaret eder. Buna göre Spinoza'nın Hayy Bin Yakzan'ın çevirmeni olduğunu gösteren en önemli bulgulardan biri Rosenthalina kütüphanesinde bulunan Spinoza'nın Opera Postuma ismiyle yayımlanan eseriyle aynı ciltte, çevirmeni S.D.B. olarak belirtilen Hayy Bin Yakzan'ın Hollandaca çevirisinin bulunmasıdır. Buradan hareketle Meijer, bu harflerin Benedictus De Spinoza'nın baş harflerinin tersten yazılışı olduğunu 
ve bu kullanımın Spinoza'nın diğer eserlerinde de görüldüğünü öne sürerek, Hayy Bin Yakzan'ın çevirmeninin Spinoza olduğu hükmüne varır (Bayraktar, 2013: 2). Yine diğer bir bulgu A. Wolf'un özel kütüphane katalogunda bulunan Hollandaca Hayy Bin Yakzan'dan bahsederken "Çeviri muhtemelen bizzat Spinoza'nındır." ifadesinin kullanılmasıdır (Bayraktar, 2013: 4). Tüm bu ve benzeri bulgulardan ve Spinoza'nın Ethica'da Hayy Bin Yakzan'dan etkilenmiş olduğu olgusundan hareketle, Bayraktar Spinoza'nın Hayy Bin Yakzan'ın çevirmeni olduğu iddiasının kuvvetle muhtemel olduğu sonucuna varır.

Tüm bu ve benzeri değerlendirmeler dikkate alındığında, Hayy Bin Yakzan'ın geç dönem Batı düşünürleri üzerinde önemli ölçüde etkileri olduğunu ve bu etkinin yeni çalışmalarla daha açık şekilde gün yüzüne çıktığını ifade etmek mümkün görünmektedir. Ancak bizim burada dikkat çekmek istediğimiz asıl mesele, bu etkinin mahiyeti ve ne ölçüde olduğundan çok, bu etkiyi doğrudan tespit edebilecek verilere sahip ol(a)mamamız hususudur. Daha açık bir ifadeyle bizim bu etkiye dair atıfları ne Locke ya da Spinoza gibi düşünürlerin kendi eserlerinde ne de hâkim Batı düşünce tarihi literatüründe doğrudan bulamıyor olmamız hususudur.

Bu durumda İbn Tufeyl'in Batı düşünürleri üzerindeki etkisine dair doğrudan kanıtların niçin bulunmadığını sormak ve nedenleri üzerine bir değerlendirmede bulunmak oldukça makul görünmektedir. Gerçekten de Russel yaptığı incelemenin sonunda bu soruyu çarpıcı bir şekilde şöyle ifade eder:

Aynı zamanda şu ifade edilmelidir ki, Locke'un kitabı okuduğu ya da bir kopyasına sahip olduğuna dair doğrudan bir ifade bulunmamaktadır... Bununla birlikte Locke'un neden kitaba atıfta bulunmadığı sorusu ortaya çıkmaktadır. Oldukça güçlü delillere rağmen böyle bir ihmal adeta kasıtlıymış gibi görünür (Russel, 1994: 252).

Benzer bir soruyu Bayraktar, Spinoza ve İbn Tufeyl arasındaki ilişkiyi ortaya koyduktan sonra şu şekilde sorar:

Böyle olduğu halde Spinoza üzerine özel çalışmış olan Batılı günümüz mütehassısları Spinoza'dan Hayy Bin Yakzan'ın çevirmeni olarak niçin hiç bahsetmiyorlar veya en azından meseleyi tartışma konusu yapmıyorlar (Bayraktar, 2013: 5).

Bu soruları cevaplandırırken Russel Locke'un kişisel özelliklerinden, Bayraktar ise Batılıların kibirlerinden hareketle bu durumu açıklamaya çalışır. Şüphesiz bu değeārlendirmelerin haklılık payı olmakla birlikte, bu olguyu izah etmeye yardımcı olacak daha genel ve açıklayıcı gücü daha yüksek değerlendirmelerden de söz etmek gerekir. Bu olguyu açıklamak üzere dikkate almamız gereken en önemli açıklamalardan biri, Batı düşünce tarihinde kaynak gösterme alışkanlığının çok geç dönemlere kadar bulunmaması ve bu nedenle de etkilendikleri öncülleri hakkında yeterli bilgiye sahip olunamamasıdır. Bununla yakından ilişkili bir diğer husus da, Batı düşüncesini yalnızca Batıda ortaya çıkan ve başka hiçbir medeniyete hiçbir şey borçlu olmayan bir süreç olarak ele alma eğilimindeki Avrupa merkezci yaklaşımdır.

Bunlardan birinci hususla ilgili olarak Fuat Sezgin, yaptığı geniş çaplı okumalara dayanarak, Yunanlıların öncülleri hakkında çok az ipucu veren, kaynak gösterme geleneği oldukça zayıf bir yaklaşıma sahip olduğunu ve bunun Avrupalılarda tamamen silindiğini tespit ederek, dikkate değer bir kaynak gösterme alışkanlığının ancak 18. yüzyılda ortaya çıkmaya başladığını iddia eder (Sefer, 2010: 82). Şüphesiz bu olguyu 
destekleyecek hemen her bilim dalından somut örnekler ortaya koymuş olmasıyla birlikte, felsefe alanından verdiği örnekler konumuz açısından dikkate değerdir. Örneğin Sezgin, Boethius'un Latince eserlerinde İbn Sîna ve Gazzâli'nin kitaplarını kullandığı anlaşıldığ 1 halde, onun bu kaynakları zikretmediğini belirtir. Yine Gundissalinus'un en önemli eseri De divisione philosophiae'nın büyük bir bölümünün Fârâbî'nin İhsâü'lUlûm 'undan kopya edildiğini ve kaynak gösterilmediğini ortaya koyar. Bunlar ve diğer bilim alanlarındaki birçok benzer durumdan hareketle Sezgin, Arapça kaynaklar ve içerikleriyle olan bu ilişki tarzının, İslam bilimlerinin Avrupa'da özümsenmesi sürecinde yalnızca Gundissalinus ya da Boethius'da karşılaşılan tikel bir fenomen olarak değil, o dönem kültür dünyasının kaynaklarla olan ilişkisinin genel bir tasviri olarak ele alınması gerektiği yargısında bulunur (Sezgin, 2014: 195-196). Dolayısıyla Avrupalı düşünürlerin eserlerinde Müslüman öncülerinin metinlerine kimi zaman kelimesi kelimesine varan bir benzerlik görülmesine rağmen, öncüllerinden hiç söz edilmemesi ya da kaynak olarak atıfta bulunulmaması yukarıda işaret ettiğimiz olgunun açık bir yansıması olarak değerlendirilebilir.

Öte yandan genel olarak Müslüman filozofların ve özelde de İbn Tufeyl'in Avrupa düşünce tarihine yaptığ 1 katkıları doğrudan tespit edemememizin en temel nedenlerinden bir diğeri, Batı ve diğerleri arasında kökensel bir ayrım yaparak Batıyı merkeze koyan yaklaşımdır denilebilir. Bu bakış açısı ve bunun üzerine temellenen tarih kurgusu, Batılı düşünürlerin tüm fikirlerini ve kökenlerini yine Batı medeniyetine ait ve ondan kaynaklanan bir olgu olarak ele alma eğiliminde olduğundan, Batı düşüncesine diğerlerinin katkısını görmezden gelen bir imge perdesi işlevi görmektedir. $\mathrm{Bu}$ bağlamda İbn Tufeyl'in Avrupalı filozofların gerçek manada öncülerinden biri olmasına rağmen, Batılı teorisyenlerin onun bu etkisini görmezden gelmesi bu çerçevede değerlendirilebilir (Attar, 2007: 2).

Nispeten uzun sayılabilecek tüm bu değerlendirmeler dikkate alındığında, genel olarak Müslüman fillozofların özelde de İbn Tufeyl'in Batı düşüncesi üzerinde derin etkileri olmasına rağmen, bu etkilerden söz edilmemesi ya da kaynaklar arasında zikredilmemesi olgusunun nedenlerinin daha açık bir şekilde ortaya çıktığı ifade edilebilir. $\mathrm{Bu}$ işaret ettiğimiz hususlar bizim esas konumuz olan Kant'ın birinci antinomideki görüşleri ile İbn Tufeyl arasındaki ilişkiyi değerlendirme bağlamında büyük ölçüde geçerli ve zorunlu olarak dikkate alınması gereken hususlardır. Bunun temel nedeni, yukarıda zikrettiğimiz örneklerde olduğu gibi, Kant'1n birinci antinomideki görüşlerinin içerik olarak İbn Tufeyl'in görüşlerine büyük ölçüde benzerlik göstermesine rağmen, ne Kant'ın kendisi tarafından ne de Kant üzerine yapılan çalışmalarda bu durumdan neredeyse hiç söz edilmemesidir.

$\mathrm{Bu}$ çerçevede Guyer'in Kant'ın birinci antinomideki kaynaklarına dair yazdığı dipnotta sergilediği tavır, yukarıda söz ettiğimiz duruma çarpıcı bir örnek olarak alınabilir. Guyer evrenin zamanda başlangıcı olduğu tezi lehindeki kanıtı değerlendirdiği dipnotunda, bu argümanın Batı felsefe-teoloji geleneğinde uzun bir geçmişe sahip olduğunu belirterek, Kant'ın bunu hangi kaynaktan aldığının açık olmadığını dile getirir. Daha sonra argümanın ilk olarak 490-570 yılları arasında yaşamış fillozof John Philoponus'ta karşımıza çıktığını ve ortaçağlarda ise Boneventura'nın (d.1217-ö.1274) bu argümanı kullandığını belirtir. Bu argümanla ilgili tartışmalar bağlamında Thomas Aquinas ve William of Ocham'dan da söz ettikten sonra, Kant'1n bu argümanı bu ortaçağ düşünürlerinden ya da belli bir kaynaktan alıp almadığına dair doğrudan bir bilgiye sahip olmadığımızı belirterek, en muhtemel kaynağın argümanın modern 
savunucusu olan Richard Bentley (d.1662-ö.1742) olabileceğini ifade eder (Guyer, 2009: 743).

$\mathrm{Bu}$ değerlendirmede dikkatleri çekmek istediğimiz husus, zikredilen isimlerin doğruluğu ya da Kant'a etki edip etmedikleri meselesi değildir. Daha çok zikredilen isimlerin hep Batılı düşünürler olması ve Philoponus'tan Boneventura'ya geçerken aradaki 6-7 yüzyıllık sürecin direk atlanmasıdır. Oysa bu dönemde başta Gazzâli ve İbn Rüşd gibi çok önemli İslam fillozofları mevcuttur ve bunların Batıya doğrudan etkisi açık bir şekilde bilinmektedir. Özellikle âlemin başlangıcıyla ilgili tartışmalarda Thomas Aquinas ve Boneventura'nın İbn Rüşd ve Maimonides gibi İslam medeniyet havzasında yetişmiş filozoflardan etkilendiği ve onlar vasıtasıyla bu konulardan haberdar oldukları açıkça ifade edilebilir (Wolfson, 2001: 355). Dolayısıyla Kant'ın birinci antinomideki kaynaklarıyla ilgili bir değerlendirmede, bu İslam filozoflarından da mutlaka söz edilmesi tabi bir durum olarak gerekli görünmektedir. Ancak yukarıda işaret ettiğimiz değerlendirmede bu isimlerden herhangi bir şekilde bahsedilmeden yalnızca Batılı isimlere yer verilmektedir. Kanaatimce bu tavır işaret ettiğimiz Batı merkezci yaklaşımın tipik bir tezahürü olarak ele alınabilir ve bu haliyle Batılı düşünürlerin Müslüman kaynaklarına ulaşabilmede önemli bir engel teşkil etmektedir.

Sonuç olarak gerek Batı kültür dünyasının kaynak göstermedeki yetersiz tavrı gerekse de Batı merkezci paradigma, Batı düşünce tarihinin Müslüman kaynaklarına doğrudan erişimi büyük ölçüde engellemektedir denilebilir. Dolayısıyla Kant'ın birinci antinomi bağlamında İbn Tufeyl'den etkilendiğine dair doğrudan verilerin bulunmaması, böyle bir etkilenmenin olmadığını kesin bir şekilde göstermez. Bu durumda yapılması gereken söz konusu düşünürün etkilendiği iddia edilen düşünüre erişebilme imkanının ortaya konması ve içerik karşılaştırması yaparak ne ölçüde benzer olduğunun belirlenmesidir.

Bu çerçevede Hayy Bin Yakzan'ın başta o dönemin yaygın dili Latince olmak üzere, Felemenkçe ve İngilizce gibi belli başlı Avrupa dillerine çevrilmiş olması ve Locke, Spinoza gibi filozofların bu kitaptan haberdar olma süreçlerine dair yaptı̆̆ımız değerlendirmeler, Kitabın o dönemde erişilebilir ve yaygın bir şekilde dolaşımda olduğunu gösterir niteliktedir. Buna ilaveten Kant'1 en çok etkileyen ve düşünceleri üzerinde doğrudan tesiri bulunan Leibniz'in Hayy Bin Yakzan'dan haberdar olması ve onu Arapça felsefi geleneğin mükemmel bir örneği olarak değerlendirmesi (Russel, 1994: 228) olgusu da dikkate alındığında, Kant'ın bu eserden ve içeriğinden doğrudan ya da dolaylı olarak haberdar olduğundan şüphe etmeyi gerektirecek makul bir sebep olmadığı ifade edilebilir. Bu durumda İbn Tufeyl'in Kant'ın birinci antinomideki görüşleri üzerinde etkili olup olmadığına dair iddiayı değerlendirmek üzere bu iki filozofun konu hakkındaki argümanlarının karşılaştırılması büyük ölçüde belirleyici olacaktır.

\section{2. İbn Tufeyl ve Kant'ın Argümanlarının Karşılaştırılması}

Daha önce farklı vesilelerle ifade ettiğimiz üzere, Hayy Bin Yakzan'da ortaya konulan felsefi görüşlerin Batılı düşünürler üzerindeki etkisi bağlamında dile getirilen hususlardan biri de, İbn Tufeyl'in Kant'1n birinci antinomideki görüşlerinin öncüsü olduğuyla ilgili değerlendirmelerdir (Siddıkî, 1990: 154-Goodman, 2007: 375). Bu değerlendirmelerin dayandığı zemin, her iki filozofun da âlemin yaratılması lehindeki ve aleyhindeki argümanların eşit güçte olduğu, dolayısıyla da aklın sınırları dâhilinde birinin tercih edilemeyeceği hususunda görüş birliği içinde olmalarıdır. Bu kısımda bu benzerlik iddiasını biraz daha detaylı şekilde ele alarak, söz konusu benzerliğin mahiyetini ortaya koymaya çalışacağız. 
Ele alınan argümanların benzerliğinden önce, iki filozofun konu bağlamında zihnî ve tarihî süreç bakımından da benzerliklere sahip olduğu ifade edilebilir. İlk olarak her iki filozofun bulunduğu dönem öncesinde âlemin kıdemi ve hûdusu lehinde görüş beyan eden iki taraf ve bunlar arasında süre giden bir tartışma ortamı mevcuttu. İbn Tufeyl'den önce âlemin kıdemini savunan filozofların temsilcisi olarak Fârâbî ve İbn Sînâcı görüşler ile âlemin hûdusunu savunan kelamcıların temsilcisi Gazzâli arasındaki şiddetli tartışma ve uzlaşmazlık o dönemin felsefesi problemlerinin başında geliyordu. Dolayısıyla bu ortamın her iki gelenekten de büyük ölçüde olumlu yönde etkilenen İbn Tufeyl'in, âlemin yaratılması konusunda her iki görüşün eşit güçte olduğu sonucuna varmasının tarihî arka planı olduğu ifade edilebilir. Benzer şekilde Kant'tan önce Newton ve Leibniz'in zaman teorileri ve buna bağlı olarak âlemin yaratılmasıyla ilgili farklı görüşleri o dönemde iki ayrı geleneği temsil ediyordu. Bu iki farklı yaklaşım arasındaki çatışmanın ifadesi olan Leibniz-Clarke arasındaki mektuplaşmanın Kant'1 antinomi fikrine götüren en önemli kaynaklardan biri olduğu (Al-Azm, 1972: 7) dikkate alındığında, Kant'ın büyük ölçüde etkilendiği Leibniz ve Newtoncu görüşler arasındaki çatışmanın onu bu düşünceye sevk eden tarihi arka plan olduğu ifade edilebilir. Bu değerlendirmeler doğrultusunda İbn Tufeyl ve Kant'ın, âlemin kıdemini ve hûdusunu savunan farklı gelenekler arasında çatışmanın etkin olduğu bir dönemde bulundukları ve bu atmosferin onları uzlaştırıcı bir çözüm arayışına sevk eden tarihî arka plan olduğunu öne sürmek oldukça makul görünmektedir.

Öte yandan iki filozofun konuyu ele alırken içinde bulundukları zihnî süreç de birbirine oldukça benzemektedir. Her iki filozof da âlemin yaratılması probleminin kendilerini en çok meşgul eden mesele olduğunu ve bunun, meselenin iki tarafından birini tercih etmedeki zorluktan kaynaklandığını ifade eder. Örneğin İbn Tufeyl birçok felsefi ve metafizik problemleri ele alıp çözüme ulaştırdığ 1 eserinde, âlemin yaratılması meselesinin Hayy'ı yıllarca uğraştırdığını, ancak bir çözüme ulaşamadığını açıkça belirtir:

[Hayy] acaba bunlar yoktan olan bir şey mi yoksa eski mi ve hiçbir vecihle yokluk ona takaddüm etmemiş mi? diye düşündü. Şek ve tereddüt içinde kaldı. İşbu iki ihtimalin hiçbirisini hükm-i kat'i ile diğerine racih bulmadi.

Hayy Bin Yakzan senelerce tereddüt içinde kaldı. Hep düşünüp durdu. Deliller, hüccetler zihninde çarpışırdı. Kıdem ve hûdus itikatlarından hiçbirisini diğerine tercih edemezdi. (İbn Tufeyl, 2006: 57).

Benzer şekilde Kant da kendisini en çok etkileyen ve eleştirel felsefeyi geliştirmeye sevk eden asıl problemin başta âlemin başlangıcı olmak üzere antinomilerdeki problemler olduğunu çarpıcı bir şekilde ifade eder:

Beni dogmatik uykumdan uyandıran ve aklın kendisiyle görünüşteki çelişkisinin neden olduğu skandalı çözmek için, aklın kendisini eleştirmeye sevk eden ilk şey Tanrı'nın varlığı, ahlak ve diğer şeylerin incelenmesi değildi; daha çok -'evrenin başlangıcı vardır' 'evrenin başlangıcı yoktur', 'özgür insan vardır' buna karşılık 'özgür insan yoktur, yalnız zorunluluk vardır'- gibi salt aklın antinomileriydi (Kant, 1967: 252).

Açıkça görüleceği üzere her iki filozof da, âlemin yaratılması konusunun zihnî serüvenlerinde belirleyici bir etkiye sahip, çözülmesi zor bir problem olduğunu ve 
bunun temel nedeninin birbiriyle çelişik iki görüşten birini tercih etmedeki zorluk olduğunu ifade etmekte ve bu haliyle de birbirine oldukça benzemektedir.

Bununla birlikte karşılaştırmamız açısından asıl belirleyici olan, iki filozofun öne sürdüğü argümanların birbiriyle ne ölçüde benzer olduğu hususudur. $\mathrm{Bu}$ açıdan bakıldığında öncelikle her iki filozof da ilk olarak âlemin yaratılmış olduğu iddiasını, daha sonra da âlemin ezeli olduğu meselesini ele alıp bunlar lehindeki argümanları ortaya koyar. Yine her iki filozof, kıdem ve hûdus lehinde ele aldıkları argümanlarda, iddiaları için doğrudan bir delil ileri sürmek yerine iddianın aksi durumu kabul ederek işe başlar ve bunun bir çelişkiye neden olduğunu göstererek iddianın doğruluğunu ispatlamaya çalışır.

$\mathrm{Bu}$ yöntem çerçevesinde İbn Tufeyl ve Kant ilk olarak âlemin yaratılmış olduğunu göstermek için âlemin ezeli olduğunu varsayarak işe başlar. İbn Tufeyl bu varsayımdan sonra biri âlemin mekânda sınırlı olduğunu gösteren delile atıfta bulunan, diğeri de var olan şeylerin yaratılmış olmasına atıfta bulunan iki delil ortaya koyar. Bunları şu şekilde ifade eder:

Âlem-i ekberin kadim olduğunu itikat etmek istediği zaman [varsaydığında] nihayetsiz bir imtidadı haiz bir cismin muhal olduğunu zihninde yerleştirmeye sebep olan delile benzer bir delil vasitasıyla nihayetsiz olmayan bir vücudun da muhal olması gibi birçok mânialar, arızalar sedd-i hail teşkil ediyordu. Ve yine işbu vücudun havadisten hâli olmadığını gördü ve havadisten hâli olmayan bir vücudun havadise takaddüm etmesi mümkün olmayacağından havadis üzerine takdimi mümkün olmayan herhangi bir mevcut dâhi hâdis olacaktı (İbn Tufeyl, 2006: 56).

Açıktır ki İbn Tufeyl'in buradaki asıl argümanı var olan şeylerin yaratılmış olmasına atıfta bulunan delildir. Aslında bu delil oldukça uzun felsefi-teolojik bir geçmişe sahip ve birçok kimse tarafından farklı formlarda dile getirilmiş bir delildir. Bu delilin farklı formlarından biri atomlardan yaratılmış olan cisimlerin yaratılmış olduğu esasına dayanır; bir diğeri doğrudan atomların yaratılmış olması esasına dayanır; sonuncu türü ise atomlardan oluşmuş oldukları dikkate alınmadan cisimlerin yaratılmışlığı üzerine bina edilir (Wolfson, 2001: 310). Bu husus dikkate alındığında İbn Tufeyl'in, argümanın atomları dikkate almayan doğrudan cisimlerin yaratılmışlığı üzerine temellenen formunu esas aldığı açıkça görülecektir. Bu argümanı Gazzâli'nin de kullandığını öne süren Goodman, argümandaki kıyasın orta teriminin yeni, sonradan olan ve olay anlamındaki hâdis (hādith) terimi olduğunu ifade eder (1971: 73). Burada eski, kadim ve sonsuz olana zıt anlamdaki bu terimin, argüman bağlamındaki en temel anlamı sonlu bir zaman önce varlığa gelen bir şey olmasıdır (Goodman, 1971: 74).

$\mathrm{Bu}$ husus temel alındığında delilin birinci önermesi bütün olarak âlemin sonradan yaratılmış olanlardan başka bir şey olmadığını ya da âlemin sonradan var olan şeylerin bir bütünü olduğunu ifade eder. $\mathrm{Bu}$ öncül argümanın diğer formları da dikkate alındığında âlemin arazlardan ayrı var olmayan atomlardan ya da arazlardan ayrı olmayan cisimlerden meydana geldiğini ve arazların var olup yok olan ve dolayısıyla da yaratılmış şeyler olduğu hususu üzerine temellenir (Wolfson, 2001: 306). Buna göre âlemi oluşturan atomlar ya da cisimler yaratılmış arazlardan oluştuğundan onlar da yaratılmıştır.

Burada zamanda meydana gelmiş şeylerden ayrı olamayan şeylerin, yani atomların ya da cisimlerin yaratılmış olması gerektiğine karşı, atom veya cisimlerin kendisinin yaratılmamış olduğunu, yalnızca arazların yaratılmış olduğunu ve bunların cisimler 
üzerinde sonsuza kadar birbiri ardına geldiklerini ileri sürerek itiraz edilebilir. Bu itiraza karşı argüman taraftarları, bunu kabul etmenin zamanda meydana gelmiş şeylerin sonsuz bir art arda gelmenin sonucu olduğu anlamına geleceğini belirtir. Oysa sonsuz teselsül imkânsız olduğundan bu mümkün değildir (Wolfson, 2001: 307). Aşağıda daha ayrıntılı ele alacağımız sonsuz teselsülün imkânsızlığı meselesi her ne kadar ayrı bir argüman olarak ele alınsa da, görüleceği üzere incelediğimiz delilin temel bir öncülü olarak, onun tarafından içerilir ve onun bir parçasıdır. Tüm bu değerlendirmeler dikkate alındığında, cisimler yaratılmış arazlardan oluştuğundan onlar da yaratılmıştır ve bütün olarak âlem de cisimlerden oluştuğundan o da yaratılmışların toplamından başka bir şey olmayacaktır sonucuna ulaşır.

İkinci önerme de ise bütün olarak âlemin sonradan yaratılmışlardan ayrı bir şey olmadığından, sonradan yaratılmışlara takaddüm etmesinin yani onlardan önce var olmasının mümkün olmayacağı dile getirilir. Çünkü bütün kendisini oluşturan parçalardan başka bir şey olmadığından, âlem de onu oluşturan cisimler ve arazlarından başka bir şey değildir ve onlardan önce var olamaz. Dolayısıyla sonradan yaratılmış olan şeylerden önce olamayan herhangi bir varlık da zorunlu olarak yaratılmış olacağından, bütün olarak âlem de hâdistir, sonlu bir zaman önce yaratılmıştır.

Daha önce işaret ettiğimiz üzere, İbn Tufeyl'in âlemin hûdusuyla ilgili asıl argümanı varlıkların yaratılmış olmasına dayanan bu delil olmakla birlikte, o ikinci bir argüman olarak âlemin mekânda sonlu olmasını gösteren delile işaret ederek, bu delilin aynı şekilde âlemin hûdusunu da gösterdiğini ifade eder. Âlemin mekânda sonluluğunu göstermek üzere sunduğu delil (İbn Tufeyl, 2006: 53), sonsuz büyüklüklere herhangi bir nicelik eklenip çıkarıldığında, karşımıza çıkan çelişik durum üzerine temellenir. Bu yaklaşımı zaman uyarlarsak, belli bir andan önceki geçmiş zaman ve sonra gelecek zaman sonsuzlukta eşit olacaktır. Ancak geçmişten belli bir zamanı çıkarıp gelecek zamana eklersek, bu durumda onlar sonsuzlukta eşit olmalarına rağmen geçmiş nicelik olarak öncekinden az, gelecek ise fazla olmuş olacaktır ki bu öncekinden daha büyük veya küçük olan bir niceliğin öncekiyle aynı olduğu gibi çelişik bir duruma neden olur. $\mathrm{Bu}$ çelişik durumun ortaya çıkmasına neden olan zamanın sonsuz olduğu varsayımı olduğundan bu yanlıştır, dolayısıyla zaman sonlu olmalıdır.

Âlemin zamanda başlangıcı vardır tezini ispatlamak üzere Kant da, bir sonsuz geriye gidişin imkânsızlığına atıfta bulunan delil ile diğeri sonsuz büyüklüklerin niceliksel özelliklerine atıfta bulunan delil olmak üzere iki argüman kullanır. Kant'ın bu tez lehine sunduğu birinci argüman, âlemin zamanda başlangıcı olmadığını varsayarak başlar. Bu durumda seçilen herhangi bir ana varıncaya kadar sonsuz bir sürenin geçmiş olması gerekecektir. Oysa bunun kabul edilmesi herhangi bir şeyin durumlarında sonsuz sayıda birbirini takip eden değişimlerin veya sonsuz sayıda olayın gerçekleştiği, diğer bir ifadeyle sonsuz bir serinin tamamlandığı anlamına gelecektir. Ancak açıtır ki, sonsuz bir seri asla ardışık serilerin birbirine eklenmesi aracılığıyla tamamlanamaz. Bu durumda tamamlanmamış veya sona ermemiş âlem serisi çelişik bir durum olacaktır. Bu çelişkiye âlemin zamanda başlangıcı olmadığı varsayımı neden olduğundan dolayı âlemin zamanda bir başlangıcı olmalıdır (Kant, 2009: 470).

Açıkça görüleceği üzere bu argümanın dayandığı temel fikir, ardışık sonsuz sayıda olayın var olduğu kabul edildiğinde, tamamlanmış bir olaylar serisinin mümkün olamayacağını ifade eder. Buna göre âlemi oluşturan ardışık olaylar serisinin bir başlangıcı olması herhangi bir şeyin mevcut olmasının zorunlu koşuludur (Al-Azm, 1972: 42). Bu kabul edilmediğinde sonsuz, aynı zamanda tamamlanmış serilerin varlığını kabul etmek gibi çelişik bir duruma düşürecektir. 
Yukarıda işaret ettiğimiz üzere sonsuz teselsülün imkânsızlığını ifade eden bu delil, en temelde şeylerin yaratılmışlığından hareket eden delile içkindir ve onun bir parçasını oluşturur. Çünkü yaratılmış şeylerin varlığının bütün olarak âlemin yaratılmış olduğunu gösterebilmesi ancak sonsuzca geriye gidebilme imkânının reddedilmesiyle mümkündür. $\mathrm{Bu}$ bağlamda âlemin yaratılması lehinde argüman öne süren birçok düşünür bu iki argümanı birbirini tamamlayan tek bir argüman olarak ele almıştır (Wolfson, 2001: 312). Bununla birlikte farklı düşünürler tarafindan sonsuz teselsül delili müstakil bir argüman olarak da ele alınmıştır. Her halükarda âlemi oluşturan cüzlerin yaratılmışlığı ve sonsuz teselsülün imkânsızlığı delillerinin birbiriyle doğrudan bağlantılı ve âlemin hûdusu lehindeki en merkezi delil olduğu ifade edilebilir. Bu husus dikkate alındığında, İbn Tufeyl cisimlerin yaratılmışlığ 1 delilini ifade ederken, Kant'ın sonsuz teselsülün imkânsızlığı delilini dile getirmesine rağmen, iki filozofun da birbiriyle doğrudan ilişkili ve tek bir argümanın farklı yönlerinden bahsettiğini ifade edebiliriz.

Kant buna ilaveten tez üzerine ilave bir açıklama sunduğu kısımda, ikinci bir delilden daha söz edilebileceğini belirtir. Sonsuz büyüklüklerin niceliksel özelliği üzerine temellenen bu delil bir büyüklüğün, kendisinden daha büyük olunması mümkün olmayan bir büyüklükse sonsuz olacağını ifade ederek başlar. Buna göre kendisine bir veya daha fazla birim eklenip çıkarılabilen bir büyüklük sonsuz bir büyüklük olamaz. Çünkü böyle bir büyüklüğe bir birim ilave edildiğinde öncekinden daha büyük olacaktır. Dolayısıyla geçmiş olaylar serisine daima yenilerini eklemek mümkün olduğundan, âlemin zamanda sonsuz geriye gitmesi mümkün olmayacaktır. Dolayısıyla âlem zamanda başlangıcı olan sonlu bir varlıktır (Kant, 2009: 472).

Görüleceği üzere bu argümandaki temel fikir, geçmiş olaylar serisinin sonsuz olduğu kabul edildiğinde, bu serilere yeni birimler eklemek mümkün olduğundan önceki büyüklükle üzerine ilave edilmiş büyüklüğün eşit olduğunu kabul etmek gibi bir çelişkiye neden olacağıdır. Buna göre üzerine yeni birimler eklenebilen büyüklüğü sonsuz kabul etmek çelişik olduğundan, geçmiş olaylar serisi sonlu olmalıdır. Bu haliyle argüman İbn Tufeyl'in âlemin mekânda sonluluğuna atıfla dile getirdiği delilin birebir aynısıdır denilebilir.

$\mathrm{Bu}$ değerlendirme çerçevesinde ifade edilmelidir ki, âlemin zamanda başlangıcı olduğu lehinde öne sürülen deliller bunlardan ibaret değildir. Bunların yanı sıra sonsuzluk delili, atomların toplanması ve ayrılması delili, tahsis delili ve tercih delili gibi birçok argüman da vardır (Wolfson, 2001: 286). Ancak her iki filozof da bu çok çeşitli argümanlardan, en merkezi olan ve tek bir argüman olarak ele alınabilecek şeylerin yaratılmışlığı ve sonsuz teselsülün imkansızlığı delili ile sonsuz büyüklüğün niceliksel özelliğine atıfta bulunan delili kullanmıştır. Bu husus dikkate alındığında, her iki filozofun âlemin hudûsu lehinde birçok delil arasından aynı argümanları tercih etme konusunda da birebir benzerlik gösterdiği ifade edilebilir.

İkinci olarak âlemin kıdemi konusuna baktığımızda, her iki filozofun bu tez (ya da antitez) lehine sundukları argümanların adım adım birebir örtüştügünü ifade etmek mümkün görünmektedir. Bu nedenle ilk olarak iki filozofun argümanlarını ifade edip, sonra genel bir değerlendirme yapmak yerinde olacaktır. İbn Tufeyl'in argümanı şu şekildedir:

Fakat âlem-i ekberin hâdis olduğuna mûtekid olmak istediği zaman önüne başka arızalar geçti ve bu itikadına mani oldular. Zira yokluktan sonra hâdis olması zamanın ona takaddüm etmesi demek olur ve hudûsten ancak bu mana 
anlaşı1ır. Hâlbuki zamanın, hâdis olduğunu farz ettiğimiz âlemin eczâsından ve âlemden ayrılması mümkün değildir; binaenaleyh âlemin zamandan müteahhir olması anlaşılamaz. Eğer âlem hâdis ise onu ihdâs etmek için bir var eden lazımdır. Bununla beraber âlemi var eden zât niçin âlemi şimdilik var eyledi de daha evvel var etmedi? Acaba bu var eden zâta bir şey mi ârız oldu ki şimdilik âlemi îcad etmesini iktizâ eyledi? Hâlbuki meydanda var edenden başka bir şey yoktur ki ona ârız olsun. Yoksa var edenin zâtında bir değişiklik mi hâdis oldu ki evvelce îcad etmediği âlemi şimdilik îcad etmesine vesile oldu? Eğer böyle değişiklik varsa o değişikliği yoktan var eden nedir (İbn Tufeyl, 2006: 56)?

Kant'in delili ise şu şekildedir:

Evrenin zamanda bir başlangıcı olduğunu varsayalım. Başlangıç içinde hiçbir şeyin olmadığı zamanın önce geldiği varlık olduğundan, evrenin var olmadığı bir zaman, yani boş bir zaman var olmalıdır. Ancak herhangi bir şeyin boş zamanda meydana gelmesi imkânsızıdır, çünkü bu zamandaki herhangi bir an diğer bir ana kıyasla bir şeyin yokluğu ile varlığını ayırt edecek bir koşula sahip değildir (ister o şeyin kendiliğinden varlığa geldiği isterse de bir sebep tarafından varlığa getirildiği kabul edilsin). Dolayısıyla âlemde birçok seri başlayabilir, ancak âlemin kendisi bir başlangıca sahip olamaz ve dolayısıyla geçmiş zaman sonsuzdur (Kant, 2009: 471).

Görüleceği üzere her iki filozof da, âlemin zamanda başlangıcı olduğunu kabul ettiğimizde, bunun kendisinde hiçbir şeyin olmadığı boş zamanın var olduğu sonucuna götüreceğini belirtir. Bu noktada İbn Tufeyl Kant'tan ayrı olarak, bu durumun hâdis olan âlemden ayrı olması mümkün olmayan zamanın, âleme takaddüm ettiğini varsaymak gibi bir çelişkiye neden olacağından yanlış olduğu çıkarımında bulunur. Ancak her iki filozofun da asıl vurguladığı ve argümanda belirleyici olan husus, mutlak sonsuz zamanda başlangıcı olan bir âlem kabul edilmesi durumunda, âlemi oluşturan ilk olay ile zamanın homojen anları arasında nasıl bir ilişki kurulacağı problemidir (Küçükparmak, 2017: 222). Daha açık bir ifadeyle bu problem, içinde hiçbir şeyin olmadığı zamanın bütün anları homojen bir yapıda birbiriyle aynı olduğundan, âlemi başlatan olayın bu anların birinde başladığını belirlemenin mümkün olmayacağını ve dolayısıyla da âlemin zamanda başlangıcından söz etmenin anlamsız olacağını ifade eder. Kant bu imkânsız oluşun, ister şeylerin kendiliğinden var olduğu isterse de bir sebep tarafindan varlığa geldiği kabul edilsin her iki durumda da aynı kaldığını belirtirken, İbn Tufeyl bu durumu doğrudan Yaratıcının homojen anlardan birini tercih etmesinin imkânsızlığı üzerinden ele alır.

Tüm bu değerlendirmeler dikkate alındığında, her iki filozofun âlemin kıdemi ve hudûsu lehinde ele aldıkları argümanların birebir bir örtüşme içinde olduğunu iddia etmenin mümkün olduğu açıkça görülecektir. Ancak İbn Tufeyl'in Kant'in öncüsü olduğu iddialarının dayandığı asıl husus, iki filozofun bu argümanları değerlendirdikten sonra ulaştıkları sonucun aynı olmasıdır. Her iki filozof da bu argümanların aynı güçte olduğunu ve aklın sınırları içerisinde bu iki iddiadan birinin nihai olarak doğrulanamayacağını öne sürer. Örneğin İbn Tufeyl, Hayy Bin Yakzan'ın bu konu üzerine yıllarca düşündügünü, bu süreçte âlemin kıdem ve hudûsu lehindeki delillerin zihninde sürekli çarpışıp durduğunu, ancak bu delillere dayanarak bu görüşlerden birini diğerine tercih edemediğini belirtir (İbn Tufeyl, 2006: 57). Benzer şekilde Kant, bu durumu ifade etmek için tez ve antitezin birlikte bulunması anlamında 'antithetic' terimini kullanır. Bu terimin asıl anlamı, açıkça biri diğerine tercih edilemeyen iki önerme arasındaki çatışkıdır (Kant, 2009: 467). Buna göre âlemin hudûs ve kıdemini 
ifade eden birbirine zıt iki önermeden birini, aklın sınırları içinde tercih etmek mümkün olmayacaktır. Dolayısıyla her iki filozof âlemin yaratılmasıyla ilgili olarak akıl aracılığıyla nihai bir sonuca ulaşılamayacağı konusunda tam bir mutabakat içindedir denilebilir.

Tüm bu hususlar göz önene alındığında, âlemin yaratılması konusunda her iki filozofun aynı görüşü savunduğunu ve bu açıdan İbn Tufeyl'in Kant'in öncüsü olduğunu ifade etmek oldukça makul görünmektedir. Ancak, bununla beraber İbn Tufeyl'in asıl görüşünün bu olmadığını, dolayısıyla da Kant'la aralarından bu tür bir ilişkinin bulunmadığını öne süren düşünürler de vardır. Örneğin Hawi, İbn Tufeyl'in aslında âlemin kıdemi görüşünü savunduğunu, dolayısıyla da onunla Kant arasında kurulan bu türden bir ilişkinin yanlış olduğunu ifade eder.

Hawi'nin bu konu çerçevesindeki değerlendirmelerine baktığımızda, ona göre bu yanlışın temel nedenlerinden biri İbn Tufeyl'in dönemin hassas dinî meselelerini ele alırken izlediği metodun gözden kaçırılmasıdır. Ona göre İbn Tufeyl, gerek yönetici sınıfın gerekse de geleneksel toplumun tepkilerinden korunmak için, tartışmalı hassas dinî konularda asıl görüşünü gizleyen ikircikli ve belirsiz bir tavırla konuyu ele alan bir metoda sahipti (Hawi, 1974: 227). Buna göre âlemin yaratılması konusu da bu tür hassas dinî konuların başında geldiğinden, İbn Tufeyl âlemin ezeli olduğu lehindeki asıl görüşünü gizlemek için, âlemin yaratılması lehinde ve aleyhindeki delilleri ele alıp bunlardan birini tercih edemeyeceğini ifade etmiş ve böylece muhtemel tepkilerden korunmayı amaçlamıştır (Hawi, 1974: 228). Dolayısıyla Hawi'ye göre Tufeyl'in âlemin kıdem ya da hudûsunun bilinemeyeceği şeklindeki değerlendirmeleri onun gerçek görüşü olarak alınmamalı, aksine âlemin kıdemi lehindeki görüşünü gizlemek için benimsediği metodun bir ifadesi olarak görülmelidir.

Ancak Hawi'nin bu değerlendirmesi en az iki açıdan eleştirilebilir görünmektedir. İlk olarak İbn Tufeyl'in özellikle yönetici sınıf tarafından eleştirilme kaygısıyla asıl görüşlerini gizleyen ikircikli bir metot izlediği değerlendirmesi gerçeği pek yansitmamaktadır. Çünkü onun doğrudan muhatap olduğu yönetici Ebu Yakup Yusuf, oldukça açık fikirli ve âlemin yaratılması gibi hassas konularda bile her türlü görüşü tartışmaktan çekinmeyen birisiydi. Bu çerçevede İbn Rüşd'ün İbn Tufeyl ile Ebu Yakup'un âlemin kıdem ve hudûsu lehindeki görüşleri çekinmeden tartışmalarına şahitliği oldukça dikkat çekicidir (Burgel, 1992: 838). Dolayısıyla İbn Tufeyl'in belli kesimler tarafından eleştirilme kaygısıyla asıl görüşlerini gizlediği varsayımını ciddiye almak için pek bir neden olmadığı ifade edilebilir. İkinci olarak, Hawi İbn Tufeyl'in âlemin kıdem ve hudûsunun bilinemeyeceğini ifade ettikten sonra, gerçek görüşü olan âlemin kadim olduğu fikrini dile getirdiğini belirtir (Hawi, 1974: 228). Bu durum açıkça İbn Tufeyl'in asıl görüşlerini gizlemek gibi bir kaygısı olmadığını gösterir, çünkü Hawi'nin kendisi İbn Tufeyl'in asıl görüşünü kitapta ifade ettiğini belirtmektedir. Dolayısıyla Hawi'nin İbn Tufeyl'in görüşlerini gizleme niyetinde olduğu yorumu kabul edildiğinde, Tufeyl'in hem görüşlerini gizlemek için âlemin yaratılması meselesinin bilinemeyeceğini hem de hemen arkasından asıl görüşü olan âlemin ezeliliğini ifade ettiğini kabul etmek gibi saçma bir durum ortaya çıkacaktır.

Bununla bağlantılı olarak, Hawi'nin eleştirisinin dayandığı asıl argüman, Tufeyl'in âlemin kıdemi görüşünü savunduğuna dair ifadeleridir. İbn Tufeyl'in ifadeleri şu şekildedir:

Binaenaleyh bütün alem... o failin fiili ve mahlukudur. Zamanca ondan müteahhir olmasalar bile teahhür-ü zatiyle ondan müteahhirdirler. Nasıl ki 
cisimlerden bir cismi elinde tuttuğun, sonra o cismi tahrik ettiğin zaman, elinle o cismin hareketlerinin ibtidası beraber olup cismin hareketi zamanca elinin hareketinden müteahhir olmasa bile bizzat ondan müteahhirdir. Tıpkı onun gibi bütün âlem o failin mahlukudur. Zamanen değil teahhür-ü zatiyle ondan müteahhirdir (İbn Tufeyl, 2006: 59).

Hawi bu metinden hareketle, İbn Tufeyl'in âlemin kıdem ve hudûsu konusunun bilinemeyeceği görüşünü savunmadığını ya da bunu taktik gereği söylediğini ve onun asıl görüşünün bu metinde açıkça görüldüğü üzere âlemin kıdemi lehinde olduğunu ifade eder. Hawi buna ilaveten, İbn Tufeyl'in Salaman ve Asal karakterleri üzerinden ortaya koyduğu; 'felsefi kanıtlayıcı bilginin zahirî dinî bilgiden daha yüksek ve daha derin olduğu' şeklindeki görüşünün dikkate alınması gerektiğini ve bu durumun âlemin kıdemi görüşünün İbn Tufeyl asıl görüşü olduğu şeklindeki yorumunu desteklediğini ifade eder (Hawi, 1974: 229). Diğer bir ifadeyle İbn Tufeyl kanıtlayıc1 felsefi bilgiyi daha üstün gördügünden felsefi görüşü temsil eden âlemin kıdemi görüşünü kabul etmektedir.

Ancak tüm bu değerlendirmelerin, İbn Tufeyl'in âlemin kıdem ya da hudûsunun bilinemeyeceği görüşünü savunmadığını, nasıl kanıtladığını görmek oldukça zordur. Çünkü İbn Tufeyl âlemin yaratılması konusunda akıl vasıtasıyla nihai bir sonuca ulaşamayınca, problemi çözmek için her iki görüşün neticelerini değerlendirmeye alan bir strateji izler. Bu değerlendirme neticesinde hangi görüş kabul edilirse edilsin her iki durumda da bütün olarak âlemin bir yaratıcıya ihtiyacı olduğu hakikatinin değişmediği sonucuna ulaşır (İbn Tufeyl, 2006: 57-59). Buna göre İbn Tufeyl'in âlemin yaratılması konusunda ulaştığı nihai çözüm, âlemin kıdem ya da hudûsunun akıl vasitasıyla bilinemeyeceğini teslim etmekle birlikte, bu durumun âlemin yaratıcıya ihtiyacı olduğu gerçeğini değiştirmediğini ifade eder. O halde biz âlemin kadim mi yoksa hâdis mi olduğunu bilemeyiz, fakat hangi görüşü kabul edersek edelim bir yaratıcı gerektiğinden, bu görüşlerden birini tercih etmek gerçek bir problem olmayacaktır. Dolayısıyla İbn Tufeyl'in âlemin k1demini dile getiren ifadeleri, onun kıdem ya da hudûsun akı1 vasitasıyla bilinemeyeceği görüşünü savunmadığını kesinlikle göstermez. $\mathrm{Bu}$ çıkarımımızı destekleyecek benzer bir durum Maimonides'in değerlendirmelerinde de görülebilir. Nitekim Maimonides benzer gerekçelerle âlemin kıdem ya da hudûsunu burhani olarak şu veya bu şekilde ispatlayamayacağımızı öne sürmekle birlikte, bunun iki görüşten birini tercih etmekten alıkoyamayacağını belirtir ve âlemin hudûsu görüşünü tercih eder (Goodman, 2007: 376). Tüm bu değerlendirmeler dikkate alındığında, Tufeyl'in âlemin kıdemi görüşünü tercih ettiği kesin doğru olsa bile, bunun onun âlemin yaratılması konusundaki bilinemezci görüşü savunmadığı anlamına gelmeyeceğini söylemek oldukça makul görünmektedir.

Hawi son olarak Kant felsefesindeki bazı hususları nazar-1 dikkate vererek, İbn Tufeyl ile Kant arasında kurulan ilişkinin yanlış olduğunu göstermeye çalışır. Hawi'ye göre, Kant'ın antinomilerle ilgili incelemesi, bütün olarak metafiziği reddetme amaciyla aklın epistemik temellerini ve sınırlarını ortaya koymaya çalışan bir yaklaşım üzerine temellenir. Buna göre metafizik bilgi mümkün değildir ve antinomilerin nedeni aklın sınırlarının dışına yani fenomenal alanın ötesine geçmeye çalışan mahiyetidir. Oysa İbn Tufeyl metafizik bilgiyi kesinlikle mümkün görür ve onu en yüksek ve kesin düzeydeki bilgi olarak kabul eder. Bu değerlendirmelerden sonra Hawi, eğer İbn Tufeyl aklın sınırından ve aklın bu sınırı aştığında çatışkıya düşeceğinden bahsetseydi, Kant'la arasında ilişki kurmanın mümkün olabileceğini ifade eder (Hawi, 1974: 230). 
Dolayısıyla İbn Tufeyl konuyu böyle bir çerçevede ele almadığından ve metafizik bilgiyi mümkün gördügünden onunla Kant arasında kurulan ilişki yanlıştır.

Şüphesiz Hawi'nin Kant ile İbn Tufeyl'in metafizik bilginin imkânı ve antinomilerin kökeni konusundaki farklılıklarına dair işaret ettiği hususlar doğru olmakla birlikte, çıkardığı sonuç tartışmaya açık görünmektedir. Evet, Kant antinomilerin kaynağı, çözümü ya da sayısı gibi konularda İbn Tufeyl'den oldukça farklı bir yaklaşıma sahiptir. Kant antinomileri aklın doğasındaki koşulsuz olanı arama girişiminin bir neticesi olarak görür ve konuyu metafizik bilginin imkânsızlığını göstermek üzere inşa edilmiş bir bilgi sistemi içerisinde ele alır. Dolayısıyla İbn Tufeyl'in metafizik bilgiyi mümkün gören epistemolojisinden kökensel olarak farklıdır. Ancak burada dikkat edilmesi gereken husus şudur; İbn Tufeyl'in antinomilerde Kant'ın öncüsü olduğu değerlendirmesinde bulunan Siddıki (1990: 154) ve Goodman (2007: 375) gibi düşünürler, bu iki filozofun metafiziğin imkânı ve antinomilerin kökeni konularında birebir aynı olduklarını iddia ederek bu değerlendirmede bulunmazlar ve böyle bir benzerlik gerekli de değildir. Burada işaret edilen husus, âlemin kıdem ya da hudûsunun akli delillerle nihai bir şekilde bilinemeyeceği konusunda iki filozof arasında benzerlik olduğu ve İbn Tufeyl'deki bu görüşün daha sonra Kant'ın ortaya koyduğu antinomiler öğretisinin nüvesini oluşturduğudur. Dolayısıyla, yukarıdaki işaret ettiğimiz hususlar dikkate alındığında, iki filozof arasındaki benzerlik ve etkileşimin imkânına dair böyle bir değerlendirmenin oldukça makul göründüğü ifade edilebilir.

\section{Sonuç}

Tüm bu değerlendirmeler dikkate alındığında, İbn Tufeyl'in birinci antinomide Kant'ın öncüsü olduğu iddiasının iki temel husus çerçevesinde değerlendirilebileceği söylenebilir. Bunlardan birincisi, Kant'in İbn Tufeyl'den haberdar olabilmesinin mümkün olup olmadığının ortaya konulmasıdır. Bu çerçevede Hayy Bin Yakzan romanının önemli Batı dillerine çevrilmiş, o dönemde yaygın bir şekilde dolaşımda olan bir eser olması olgusuna işaret ettik. Öte yandan Locke, Spinoza ve Leibniz gibi önemli filozofların bu eserden haberdar olmaları hususunu da buna ilave ettiğimizde Kant'ın, bu eser ve içeriğinden doğrudan ya da dolaylı bir șekilde haberdar olması önünde makul bir engelin bulunmadığını ifade ettik.

Bunun yanı sıra benzerlik iddiasını belirleyecek asıl hususun, konu bağlamındaki görüşlerin içerik karşılaştırması olduğunu belirttik. Bu doğrultuda yaptığımız değerlendirmelerde, her iki filozofun gerek âlemin kıdem ve hudûsu lehinde ele aldıkları delillerin gerekse de vardıkları sonuçların büyük ölçüde benzer olduğunu ortaya koyduk. Buna ilaveten İbn Tufeyl'in Kant'in öncüsü olduğu iddiasına karş1 yönletilen bir kısım eleştirileri de değerlendirerek, bunların benzerlik iddiasını ortadan kaldıracak güçte olmadığını göstermeye çalıştık. Tüm değerlendirmeler neticesinde, 'argümanlar vasıtasıyla âlemin hudûs ve kıdemi görüşlerinden birini nihai olarak seçemeyceğimiz' konusunda İbn Tufeyl'in Kant'ın öncüsü olduğu iddiasının oldukça makul ve savunulabilir olduğu sonucuna ulaştık.

Ancak bu sonuçlar çerçevesinde iki hususa özellikle dikkat edilmesinin gerekliliği de burada vurgulanmalıdır. Bunlardan birincisi İbn Tufeyl ile Kant arasında konu bağlamında kurulan benzerlik ilişkisi, kesinlikle iki filozofun metafizik bilginin imkanına dâir görüşleri arasında bir örtüşme olduğunu ima etmemektedir. Yukarıda da ifade edildiği üzere bu benzerlik ilişkisi yalnızca alemin yaratılması lehinde ve aleyhindeki delillerden birinin tercih edilemeyeceği meselesiyle sınırlıdır. İkinci husus 
ise, bu ilişkinin ortaya konması önceki filozofun özgünlüğü ya da sonrakinin özgün olmadığı gibi felsefi düşüncenin gelişimini sahih bir şekilde anlamamıza engel olan bir yaklaşımı da ima etmemektedir. Aksine felsefî düşüncenin gelişimini sadece Batı merkezli bir süreç olarak ele alan yaklaşımın yetersizliğine işaret ederek, bu sürece katkıda bulunan tüm unsurların dikkate alınması gerektiğini göstermeyi amaçlamaktadır. Dolayısıyla bu çaba, yine yukarıda işaret ettiğimiz üzere, Kant'ın âlemin yaratılmasıyla ilgili görüşlerinin öncülleri olarak Aquinas ya da Occam'dan nasıl söz ediliyorsa, İbn Tufeyl'in de aynı şekilde onun öncüsü olarak dikkate alınması gerektiğini göstermeyi hedeflemektedir.

\section{Kaynakça}

Al-Azm, S. (1972). The Origins of Kant's Arguments in the Antinomies. Oxford: Oxford University Press.

Al-Rodhan, N. R. F. (2012). "Introduction: A Thousand Years of Amnesia". The Role of the Arap-Islamic World in the Rise of the West Implications for Contemporary TransCultural Relations. Ed. Nayef R. F. Al-Rodhan. 1-24. New York: Palgrave Macmillan.

Attar, S. (2007). The Vital Roots of European Enlightenment: Ibn Tufeyl's Influence on Modern Western Thought. Lanham: Lexington Book.

Bayraktar, M. (2013). "Hayy Bin Yakzan'ın Çevirmeni Olarak Spinoza". Beytulhikme An International Journal of Philosophy Vol 3/1, 1-16.

Burgel, J. C. (1992). "Ibn Tufayl and his Hayy Ibn Yaqzan: A Turning Point in Arabic Philosophical Writing”. The Legacy of Muslim Spain. Ed. S. K. Jayyusi. 830-848. Leiden: E. J. Brill Press.

Goodman, L. E. (1971). “Gazali’s Argüment From Creation”. International Journal of Middle East Studies Vol.2/1, 67-85.

Goodman, L. E. (2007). “İbn Tufeyl”. İslam Felsefesi Tarihi I. Ed. S. Hüseyin Nasr \& Oliver Leaman. çev. Şamil Öçal \& H. Tuncay Başoğlu. 369-388. İstanbul: Aç1lım Kitap Yayınları.

Guyer, P. (2009). "Editorial Notes". Critique of Pure Reason, Ed. and Trn. Paul GuyerAllen Wood.705-756. Cambridge: Cambridge University Press.

Hawi, S. S. (1974). Islamic Naturalism and Mysticism A Philosophic Study of Ibn Tufeyl's Hayy Bin Yaqzan. Leiden: E. J. Brill.

İbn Tufeyl. (2006). Hayy Bin Yakzan. İstanbul:Etkileşim Yayınları.

Kant, I. (1967). Philosophical Correspondence. Ed. and Trn. Arnulf Zweig. Chicago: The University of Chicago Press.

Kant, I. (2009). Critique of Pure Reason. Trn. Paul Guyer and Allen Wood. Cambridge: Cambridge University of Press.

Küçükparmak, A. (2017). Kant'a Göre Bilgi ve Metafiziğin Imkanı. İstanbul: İz Yayıncilik.

Russel, G. A. (1994). "The Impact of the Philosophus autodidactus: Pocockes, Jhon Locke and the Societyy of Friends". The Arabick Interest of the Natural Philosophers in Seventeen-Century England. Ed. Gul A. Russel. 224-265. New York: E. J. Brill Press. 
Sarton, G. (1931). Introduction to the History of Science Volume II. Baltimore: The Williams \& Wilkins Company.

Sefer, T. (2010). Bilimler Tarihçisi Fuat Sezgin. İstanbul: Timaş Yayınları.

Sezgin, F. (2014). Tanınmayan Büyük Çăg: Fuat Sezgin'in İslam Bilim ve Teknoloji Tarihinden. Ed. Resul Turan. İstanbul: Timaş Yayınları.

Sıddıki, B. H. (1990). “İbn Tufeyl”. çev. İlhan Kutluer. İslam Düşüncesi Tarihi II.Ed. M. M. Şerif. 147-161. İstanbul: İnsan Yayınları.

Wolfson, H. A. (2001). Kelam Felsefeleri: Müslüman-Hıristiyan-Yahudî Kelamı. çev. Kasım Turan. İstanbul.

Zaken, A. B. (2017). Hay Bin Yakzan’ı Okumak. çev. Yavuz Alogan. İstanbul: İthaki Yayınları. 